\title{
Access to Improved Toilet Facilities Among Predominantly Farming Communities in Izzi Local Government Area of Ebonyi State, Nigeria
}

\author{
Edwin Njoba Onyeabor* and Gibson Nwabueze Umeh \\ Department of Agricultural Economics, Management and Extension, \\ Ebonyi State University, Abakaliki, Nigeria \\ *Email of corresponding author: drenonyeabor@gmail.com
}

\begin{abstract}
The study assessed access to improved toilet facilities among prominently farming communities in Izzi Local Government Area of Ebonyi State, Nigeria. The influences of household's demographic and socio-economic factors on access to improved toilet facilities in the area were also determined. Multi-stage random sampling procedure was used to select 240 respondent-households used for the study. Data were collected through interview schedule and analyzed with descriptive and inferential statistics, including percentages and probit regression analysis. Result showed that $79.6 \%$ of the respondent-households were male-headed; mean age of heads of households was 54years; $80 \%$ were famers; and $72.5 \%$ had no formal education. Average size of households was 7 members while average yearly household income was $126,458.33 \mathrm{k}$ (equivalence of \$346.46). About 1 out of 5 households in the area (or 13.9\%) had access to improved toilet facilities while $86.1 \%$ used unimproved facilities including open defecation $(29.2 \%)$ and shared toilets $(20.7 \%)$. Result from probit regression analysis showed that the overall fit of the model was good at 9368.836 , which was significant at $1 \%$ level. Furthermore, household's size (0.27), annual income (0.41) and main occupation of head (0.87) showed positive and highly significant relationship with access to improved toilet facilities at $1 \%$ level while sex (8.49) and education (8.75) were also both positive but significant at $5 \%$ and $10 \%$ levels respectively. It was concluded that access to improved toilet facilities was low in the study area and that it was influenced by demographic and socio-economic characteristics of households. Mass campaign was recommended while on-going effort to improve adult literacy and rural income through agriculture was encouraged.
\end{abstract}

Key words: Access to improved toilets, Unimproved toilets, Farming communities, Ebonyi State, Nigeria

DOI: $10.7176 / J E E S / 9-11-12$

Publication date: November $30^{\text {th }} 2019$

\section{Introduction}

Access to improved toilet facilities is a topical developmental issue that touches on the health and wellbeing of rural communities. Adequate toilet, together with good hygiene and safe water are fundamental to good health and socio-economic development hence, Mara, Lane, Scott and Trouba (2010) noted that improved toilet is more important than independence. As a component of the global issue of access to water and sanitation, which ranked among the Millennium Development Goals, world-wide interest has been generated and a lot of international resources have been spent to give access to improved toilet facilities by rural communities in developing countries of the world. Toilet has been defined as the sanitation structure of safe disposal of human excreta (Mara, Lane, Scott and Trouba, 2010). The phrase safe disposal implies not only that people must excrete hygienically but also that their excreta must be contained or treated to avoid adversely affecting their health or that of other people.

Toilet facilities are categorized into two namely: improved and unimproved toilet facilities (Mara, Lane, Scott, Trouba 2010; Hazarika, 2015). Improved toilet facilities are the facilities that ensure hygiene separation of human excreta from human contact. They include Flush or Pour Flush toilet/latrine, Ventilated Improved Pit (VIP) latrine, Pit Latrine with slab and 
Composting Toilet. Unimproved toilet facilities are those that do not ensure hygiene separation of human excreta from human contact. They include Pit Latrines without slab, Hanging Latrines and Bucket Latrines, Shared Toilet facilities (shared between two or more households, including public toilets), open defecation which include defecation in the fields, forests, bushes, bodies of water or other open spaces, or disposal of human faeces with solid waste (WHO, 2007; Mara, Lane, Scott, Trouba, 2010; UNICEF/WHO, 2015).

Since 1999, great progress has been made by the world on the provision and use of improved toilet facilities in the developing regions of the world. The greatest progress reportedly, has been made in Eastern Asia, where sanitation coverage has increased from 27\% in 1990 to $67 \%$ in 2011 (UNICEF, 2008; UNICEF/WHO, 2012; UNICEF, 2015). However, UNICEF/WHO (2015) and Septeien (2015) estimated that 2.5 billion people (37\% of the world's population) still lack access to improved toilet facilities. The authors also observed that a little over 1 billion (14\% of the world population) remain with no access to toilets, latrines or any form of toilet facility, and therefore practiced open defecation. The results of this practice were high levels of environmental contamination and exposure to the risks of microbial infections, diarrhoea diseases (including cholera), trachoma, schistosomiasis and hepatitis (Cairncross, Hunt, Boisson, Bostoen, Curtis, Fung and Schmidt, 2010; UNICEF/WHO, 2015). Nine hundred and two million (902 million or $90.2 \%$ ) of those without any access to any form of toilet facility reportedly, live in rural areas (Agbolade, Akinboye, Fajebe, Abplade and Adebambo, 2008; Simonnat, Gireandot-Leipma n, 2013 ; UNICEF/WHO, 2015). Current trends show sub-Saharan Africa and Southern Asia still struggle with low sanitation coverage (UNICEF/WHO, 2015). In sub-Saharan Africa, 44 per cent of the population uses either shared or unimproved facilities, and an estimated 26 per cent practices open defecation, surpassed only by Southern Asia (39 per cent; UNICEF/WHO, 2015). In Nigeria, 45million people reportedly, still defecate in the open and another 130 million use unimproved and shared toilet facilities (UNICEF/WHO, 2015).

A lack of improved toilet leads to disease. Poor hygiene and lack of access to toilet together contribute to about $88 \%$ of deaths from diarrheal diseases (Cairncross, Hunt, Boisson, Bostoen, Curtis, Fung and Schmidt, 2010; Josh, Fawcett and Mannan, 2011). The diseases associated with poor toilet facilities are particularly correlated with poverty and infancy and account for about $10 \%$ of the global burden of disease (UNICEF/WHO, 2015). Of human excreta, faeces are the most dangerous to health. One gram of fresh faeces from an infected person can contain around $10^{6}$ viral pathogens, $10^{6}-10^{8}$ bacterial pathogens, $10^{4}$ protozoan cysts and $10-10^{4}$ helminthes eggs (Mara et a I, 2010). According to Mara et al (2010), due to use of unimproved toilet facilities, sanitation-related diseases such as diarrhea disease, Neglected Tropical Diseases, Acute Respiratory Infections, under-nutrition, schistosomiasis, present among the people leading to high death rate and reduced labour force. Toilet as a sanitation fixture and hygiene are keys to child survival, development and growth. Improved toilet has yet to reach 2.5 billion people in the developing world - almost 980 million of which are children under 18 years old (UNICEF/WHO, 2015). Similarly, UNICEF/WHO (2015) noted that about half of the approximately 120 million children born in the rural communities each year live in households without access to improved toilet, which poses grave risk to their survival and development. Achieving improved access to sanitary toilets and hygiene in Africa was projected to result in 173 million cases of diarrhea being avoided every year (UNICEF, 2015). 
Improved toilet leads to less environmental degradation, increased sustainability of environmental resource and a more secure future for children (UNICEF, 2008; WHO, 2010; UNICEF, 2012; UNICEF/WHO, 2015). It also leads to social development. Schools that have access to water and toilet attract and retain students, particularly girls (UNICEF, 2008; UNICEF/WHO, 2015). Improved toilet as a sanitation structure help to save healthcare expenses, and earn other indirect economic benefits, including decrease in work day lost to illness and longer life span (Mara et al, 2010). People without toilets at home spend a great deal of time each day queuing up for public toilets or seeking secluded spots to defecate. For women, the provision of household toilet reduces the risk of rape and/or attack experienced when going to public latrines or the bush to defecate; and for girls, the provision of school toilet facilities means that they are less likely to miss school by staying at home during menstruation (Mara et al, 2010; UNICEF/WHO, 2015). Poor sanitation generally has been estimated to cost countries between 0.5 and 7.2 per cent of their GDP (World Bank, 2015). Nigeria particularly, looses \$3 billion or 1.3\% of her GDP to poor sanitation and hygiene. On the other hand, every US \$1 spent on sanitation brings a $\$ 5.50$ return by keeping people healthy and productive. Globally, economic gains from investing in sanitation and water have been estimated at \$260 billion per year (WHO, 2004; World Bank, 2015).

Access to improved toilet facilities in most developing countries has been slowed by lack of national policy. Governments in general and health ministries in particular, cannot play their key roles as facilitators and regulators of improved toilet without policies that support the transformation of national institutions into lead institutions that increase focus on household behavior. There must also be appropriate policies that facilitate rural community action geared toward promoting demand creation and enabling health systems to incorporate toilet and hygiene (Mara, et al, 2010). The research was therefore, designed to assess the level of access to improved toilet facilities among households in the rural communities of Izzi Local Government Area (LGA) of Ebonyi State. Specifically, the research sought to (i) describe the demographic and socio-economic characteristics of respondents, (ii) identify the types of toilet facilities used, and (iii) determine the effect of demographic and socioeconomic characteristics of household heads on access to improved toilet facilities in the study area. It was hypothesized that socioeconomic characteristics of respondents had no significant effect on access to improved toilet facilities in the area. The work is aimed at providing evidence that will inform policy recommendations to policy makers in affected Local Government Council and Ebonyi State Government towards achieving total access to improved toilet in the study area and the rural areas of the state generally.

\section{Methodology}

The research work was carried out in Izzi Local Government Area (LGA) of Ebonyi State. Izzi is one of the oldest and largest Local Government Areas in Ebonyi State. The area is about 723.1 square kilometers (Chima, 2013). The population of the area was about 367,659 in 2006 and is projected to be about 511,046 by the end of 2019 at $3 \%$ annual growth rate (NPC, 2006). Izzi LGA lies between latitude $45^{\circ}$ and $760^{\circ}$ of the Green which meridian and between $45^{\circ}$ and $50^{\circ}$ North of the equator. Rainfall is $1800-2000 \mathrm{~mm}$ perineum. The average room temperature is $27^{\circ} \mathrm{C}$. The natural vegetation of lzzi is derived savannah. In the northern and western parts, Izzi LGA shares common boundaries with Abakaliki and Ikwo LGAs both of Ebonyi State while in the east and south it is bounded by Benue 
and Cross River States of Nigeria respectively. Major crops grown in Izzi LGA are Yam, Rice, Cassava, Sweet Potato, Bambara-nut, Melon, various vegetables and Cocoyam (Chima, 2013). Izzi LGA has its headquarters at Iboko and is made up of eight (8) autonomous communities which include: Agbaja, Igbeagu, Ndieze, Ndiezechi, Ezzainyimegu, Mgbalukwu, Ndiebo Ezzainyimegu and Ndiechi Ezzainyimmegu. The communities are organized into five Development Centers including: Ebyia, Nnodo, Amachi, Igbeagu and Izzi.

Multi-stage random sampling procedure was used to select respondents for the study. In Stage one, 4 out of the 8 autonomous communities in the LGA were selected through simple random sampling. The selected communities were Ndieze-echi, Ezzainyimegu, Ndiebor Ezzainyimaegu, Ndiechi Ezzainyimegu. In stage two, 4 villages were randomly selected from each of the four autonomous communities earlier selected in stage one to give a total of 16 villages. In stage three, 15 households were randomly selected from each of the selected villages to make a total of 240 respondent-households. Primary data were used for the study. The data were collected using interview schedule because most of the respondent heads of households were illiterates. Descriptive and inferential statistics were employed to analyze data. Specifically, objectives (i) and (ii) were analyzed using percentage distribution and means while objective (iii) was analyzed using probit regression analysis. The hypothesis was tested using F-test.

The Probit regression model is expressed implicitly as

$\mathrm{AIT}=\mathrm{B}_{0}+\mathrm{B}_{\mathrm{i}} \mathrm{X}_{\mathrm{i}}+\mathrm{et} \ldots(\mathrm{l})$

Explicitly, the model expressing the effect of respondents' socio-economic characteristics on access to improved toilet facilities is presented as:

$\mathrm{AIT}=\mathrm{B}_{0}+\mathrm{BAG}+\mathrm{B}_{2} \mathrm{SE}+\mathrm{B}_{3} \mathrm{LE}+\mathrm{B}_{4} \mathrm{HS}+\mathrm{B}_{5} \mathrm{AI}+\mathrm{B}_{6} \mathrm{MO}+$ et...(2)

Where AIT is dichotomous (categorical) dependent variable, which can be explained as: $\mathrm{AIT}=1$, access to improved toilet facilities; AIT $=0$, no access to improved toilet facilities .

$\mathrm{B}_{0}=$ Intercept

$\mathrm{B}_{\mathrm{i}}=$ regression coefficient

$\mathrm{X}_{\mathrm{i}}=$ Independent variable

et. $=$ Error term

The explanatory variables represented by $\mathrm{Xi}$ are:

$\mathrm{AG}=$ Age of respondents (years)

$\mathrm{SE}=$ Sex of respondents $($ Male $=1$, female $=2)$

$\mathrm{LE}=$ Level of education (no formal education $=0$, primary education $=6$, secondary education $=12$, tertiary education $=16$ )

$\mathrm{HS}=$ Household size (number of members of household)

$\mathrm{AI}=$ Annual personal income of the respondents (in naira,

MO = Main occupation (farming $=1$, business/trading $=2$, civil $/$ public service $=3$ ) 


\section{Result and Discussion}

\section{Demographic and socioeconomic Characteristics of Respondents}

Respondents' demographic and socioeconomic characteristics considered included sex, age, marital status, household size, educational qualification, main occupation and annual income. More (79.6\%) of the respondents (heads of households) were males, which conformed with the custom of the people of the area whereby the adult male played the role of head of household (Onyeabor and Ashiegbu, 2017). About 17\% of the respondents was within 40 years of age while a little more than half $(50.4 \%)$ was above 50 years of age. Average age of the respondents was 53.8 years. This implies that heads of households as household managers in the area were aging. Sixty percent $(60 \%)$ of the households were married and $63 \%$ had more than five members. Average household size was 7 members, which agrees with the finding of Onyeabor and Ashiegbu (2017).

Majority of the respondents $(72.5 \%)$ had no formal education, which implies that they could not read or write. According to Odoemenem and Obinne (2010), rural people/farmers who have no formal education tend to be more conservative in their practices. Expectedly, $80 \%$ of the respondents had farming as their primary occupation while $20 \%$ constituted of traders, civil and public servants. The average annual monetary income of respondents was N126,458.33k or N351.27k per day, which approximates to about $\$ 1$ per day for an average household of 7 members. If this income level is assumed to translate to consumption expenditure, then a member of an average respondent-household earned about $1 / 5$ or $20 \%$ of the international poverty line of $\$ 190$ per day ${ }^{i}$ (when average household size of 7 is adjusted to 5 adult male equivalence).

\section{Types of toilet facilities used by respondents}

Only $13.9 \%$ of respondent-households use improved toilets, which included flush toilets with septic tanks, ventilated improved pit (VIP) latrines, and pit latrines with slab. Majority of the households $(81.6 \%)$ used unimproved toilets such as pit latrines without slabs, hanging latrine, and open (bush) defecation.

Invariably, the three types of unimproved toilets are 'open' by their nature. In the use of pit toilet without slab, faeces collect in pits, which are open to air, flies, rodent and possibly, human contacts. Also, in the hanging toilets, human wastes collect in shallow pits or bare grounds from where they could easily contaminate human sources of food and water.

\section{Effects of socioeconomic characteristics of respondents on their access to improved toilet facilities}

Probit regression was carried out to analyze the effects of socioeconomic characteristics of respondents on respondents' access to improved toilet facilities. The dependent variable (Y) was access to improve toilet facilities while the independent variables included age $\left(\mathrm{X}_{1}\right)$, sex $\left(\mathrm{X}_{2}\right)$, level of education $\left(\mathrm{X}_{3}\right)$, household size $\left(\mathrm{X}_{4}\right)$, annual income $\left(\mathrm{X}_{5}\right)$ and major occupation $\left(\mathrm{X}_{6}\right)$. 
Table 1: Percentage distribution of respondents according to socioeconomic characteristics

\begin{tabular}{|c|c|c|c|c|}
\hline $\begin{array}{l}\text { Socio-economic } \\
\text { variables }\end{array}$ & Description of variables & $\begin{array}{l}\text { Frequency } \\
\mathrm{N}=\end{array}$ & Percentage & Mean \\
\hline Sex & $\begin{array}{l}\text { Male } \\
\text { Female }\end{array}$ & $\begin{array}{l}191 \\
49\end{array}$ & $\begin{array}{l}79.58 \\
20.42\end{array}$ & \\
\hline Marital status & $\begin{array}{l}\text { Single } \\
\text { Married } \\
\text { Divorced } \\
\text { Separated } \\
\text { Widowed }\end{array}$ & $\begin{array}{l}35 \\
143 \\
8 \\
29 \\
25\end{array}$ & $\begin{array}{l}14.58 \\
59.58 \\
03.33 \\
12.08 \\
10.42\end{array}$ & \\
\hline Age (years) & $\begin{array}{l}\leq 40 \\
41-50 \\
51-60 \\
>60\end{array}$ & $\begin{array}{l}41 \\
78 \\
88 \\
33\end{array}$ & $\begin{array}{l}17.08 \\
32.50 \\
36.66 \\
13.75\end{array}$ & 53.8 \\
\hline Household size & $\begin{array}{l}1-5 \\
6-10 \\
11-15 \\
\text { Above } 15\end{array}$ & $\begin{array}{l}88 \\
132 \\
16 \\
4\end{array}$ & $\begin{array}{l}36.67 \\
55.00 \\
06.67 \\
01.67\end{array}$ & 7 \\
\hline $\begin{array}{l}\text { Educational } \\
\text { qualification }\end{array}$ & $\begin{array}{l}\text { No-formal education } \\
\text { Primary } \\
\text { Secondary } \\
\text { Tertiary education }\end{array}$ & $\begin{array}{l}174 \\
33 \\
21 \\
12\end{array}$ & $\begin{array}{l}72.50 \\
13.75 \\
05.00 \\
05.00\end{array}$ & \\
\hline Main occupation & $\begin{array}{l}\text { Farming } \\
\text { Business/Training } \\
\text { Civil/Public Servant }\end{array}$ & $\begin{array}{l}192 \\
12 \\
36\end{array}$ & $\begin{array}{l}80.00 \\
05.00 \\
15.00\end{array}$ & \\
\hline Annual income & $\begin{array}{l}<100,000 \\
100,000-300,000 \\
300,001-500,000 \\
>500,000\end{array}$ & $\begin{array}{l}115 \\
92 \\
21 \\
12\end{array}$ & $\begin{array}{l}47.92 \\
38.33 \\
08.75 \\
05.00\end{array}$ & $126,458.33$ \\
\hline
\end{tabular}

Source: Field Survey, 2018. 
Table 2: Percentage of Respondents According to Types of Toilet Facilities used

\begin{tabular}{llll}
\hline Types of toilet & Description of facility & $\begin{array}{l}\text { Frequency } \\
(\mathrm{n}=353)^{*}\end{array}$ & Percentage (\%) \\
\hline Improved toilet & Flush toilet with septic tank & 20 & 05.67 \\
& Ventilated improved Pit toilet & 8 & 02.27 \\
& Pit with slab & 21 & 05.95 \\
& & & \\
Unimproved toilet & Pit latrine without slab & 52 & 14.73 \\
& Hanging latrine & 76 & 21.53 \\
& Open Defecation & 103 & 29.18 \\
Total & Shared/public toilet & 73 & 20.68 \\
\hline
\end{tabular}

Source: Field Survey, 2018. *Multiple responses recorded.

Table 3: Coefficient estimates of probit regression model of effects of socioeconomic characteristics on access to toilet facilities in the study area

\begin{tabular}{llllll}
\hline Variable name & Parameter & Coefficient & $\begin{array}{l}\text { Standard } \\
\text { Error }\end{array}$ & Z-value & $\begin{array}{l}\text { Level of } \\
\text { Significant }\end{array}$ \\
\hline Constant & $\mathrm{B}_{0}$ & 35.32 & 9.88 & 1.24 & NS \\
Age (AG) & $\mathrm{B}_{1}$ & -1.48 & 0.230 & 6.36 & $*$ \\
Sex (SE) & $\mathrm{B}_{2}$ & 8.49 & 2.83 & 3.00 & $* *$ \\
Education level (LE) & $\mathrm{B}_{3}$ & 8.75 & 3.49 & 2.50 & $* * *$ \\
Household size (HS) & $\mathrm{B}_{4}$ & 0.27 & 0.061 & 4.35 & $*$ \\
Annual income (AI) & $\mathrm{B}_{5}$ & 0.41 & 0.08 & 5.13 & $*$ \\
Main occupation (MO) & $\mathrm{B}_{6}$ & 0.87 & 0.01 & 95.05 & $*$ \\
Pearson Goodness-of- Fit & $24457.0^{*}$ & & & & \\
\hline
\end{tabular}

Source: Field Survey, 2018. ${ }^{*} \mathrm{P}=0.01(99 \%){ }^{*}, * *$, and $* * *$ indicate the $1 \%, 5 \%$, and $10 \%$ level of significance respectively.

The overall fit of the Probit model is explained by the Pearson Goodness-of-Fit which was 9368.836 and statistically significant at $1 \%(\mathrm{P} .<0.01)$ showing that the model was a good fit. The coefficient of age $\left(\mathrm{X}_{1}\right)$ was negatively signed but statistically significant at $1 \%$ which indicated that older respondents had less access to improved toilet facilities. The coefficient for sex $\left(\mathrm{X}_{2}\right)$ was positively signed and statistically significant at $5 \%$, which shows that sex of head of household increased access to improved toilet facilities. The coefficient for educational level was positively signed and statistically significant at $10 \%$, implying that formal education enhanced access to improved toilet facilities in among the respondents. The coefficient for household size was positively signed and statistically significant at $1 \%$ level of significance which implied that larger households had more access to improved toilet facilities. This result could be said to collaborate Obasi, Henry-Ukoha, Ukewuihe, Chidiebere-Mark (2013) who found out that farmers with large household sizes had higher network of information concerning new techniques. Furthermore, explanation for this result may be rooted in the culture whereby wealthier people in the communities (who could afford improved toilet facilities) marry many wives and hence, grow larger families as practiced in the area. Total annual income showed a positive linear relationship with improved toilet facilities accessibility and was statistically significant at $1 \%$. This result implied therefore, that households with higher income had more access to improved toilet facilities. This is also in line with the a priori expectation since increase in income can facilitate purchase and installation of modern toilet equipment. Respondent's main occupation was positively signed and statistically 
significant at $1 \%$. In other words, respondent's occupation showed positive linear relationship with access to improved toilet facilities, implying that the occupation of heads of households had positive influence on access to improved toilets.

Since all the independent variables are statistically significant, they all constituted good indices for estimating access to improved toilet facilities in the study area.

The Probit model estimate is shown as:

$$
\begin{aligned}
\mathrm{AIT}= & 35.32-1.48 \mathrm{AG}+8.495 \mathrm{E}+8.75 \mathrm{LE}+0.27 \mathrm{HS}+0.41 \mathrm{AI}+0.87 \mathrm{MO}+\mathrm{et} \ldots(3) \\
& (9.88)^{\mathrm{ns}}(0.23)^{*}(2.83)^{* *}(3.49)^{* * *}(0.06)^{*}(0.08)^{*}(0.01)^{*}
\end{aligned}
$$

From the result of Probit analysis as discussed above, larger households by younger, educated and wealthier male- or female-heads who have occupation are more likely to use improved toilets in the study area.

A null hypothesis, which stated that demographic and socio-economic characteristics of the respondents have no significant effect on their access to improved toilet facilities in the study area was tested using F-test. Result showed that F-cal > F-tab at both 0.05 and 0.01 levels of significance. The null hypothesis was therefore, rejected and the alternative accepted namely: demographic and socioeconomic characteristics of households in the study area significantly affect their access to improved toilet facilities. The implication of this is that policies aimed at increasing access to improved toilet facilities in the study area must provide for improvements in the socio-economic status of households for success to be achieved.

\section{Conclusion and recommendation}

The study proved that there is very low access to improved toilet facilities in Izzi Local Government Area of Ebonyi State. Moreover, among the greater percentage that used unimproved toilet facilities, use of open defecation and shared toilets which are the worst types in terms of spreading of diseases and polluting of the environment generally, were still relatively high. Furthermore, the result has demonstrated that demographic and economic characteristics of households including: sex, age, level of formal education, level of income, household size and occupation of heads of households, significantly influenced their access to improved toilet facilities. It is recommended that the appropriate governmental and nongovernmental agencies should embark on sustained advocacy to enlighten the people of Izzi LGA and indeed, other rural areas of the State, on health implications of open defecation and use of unimproved toilets. This will help to dismantle cultures and break taboos that make people choose to use open defecation and other unsanitary toilet systems even when they could afford or already have improved toilet facilities. Furthermore, the State Government's current drive towards the expansion of adult literacy program coupled with the on-going agricultural revolution program should be used to address the issues of adult illiteracy and low income, which are among the prominent factors that limit households' access to improved toilets in the area. In addition, the Ministry of Environment should as a matter of exigency, extend the on-going inspection of toilet facilities in Ebonyi State capital to the rural communities in Izzi LGA, and perhaps other rural areas in the State, through the Departments of Environment of the Local Councils. The inspection should be aimed at eradicating open defecation and use of unimproved toilet facilities as well as transferring simple, cost-effective, sustainable sanitary models of toilet to rural households. 


\section{References}

Agbolade, O.M., Akinboye, D.O., FAjebe, O.T., Abolade, O, A. and Adebambo, A.A (2 008 ). H u m a n U r i n a r y Schestosomiasis Transmisssion Foci and Period in endemic town of Ijebu North, Southwest, Nigeria. Tropical Biomedical 21:15-22.

Chima M (2013): The Geographical Location of Izzi Local Govern m e n t A rea. Martins library hlagspot.com.org

Caimcross S, Hunt C, Boission S, Bosteon K, Curtis V, Fung I.CH, and Schmidt W. (2010): Water, Sanitation and Hygiene for the Preservation of diarrhoe. International Journal of Epidemiology, 39(Suppl 1): i/93i205.doi:10.1093/ije/dyq035

Hazarika M.R (2015). Sanitation and Its Impact on Health: A Study of Jorhat, Assan. International Journal of Scientific and Research Publications, Vol. 5 Issue 10.

Josh D, Fawcett B, Mannam F (2011): Health, Hygiene and Appropriate Urbanization: Experience and Perceptions of the Urban Poor. Environment and Urbanization Vol. 23 No. 1, 91-111. doi:10.1177/0956247811398602.

Mara D, Lane J, Scott B, Trouba D (2010): Sanitation and Health. PLoS medicine. Vol. 7 No. 11.PP86

NPC (2006): Nigeria Population. National Population Census, National Population Commission, Abuja, Nigeria

Obasi PC, Henri-Ukoha A, Ukewuihe I.S. and Chidiebere-Mark N.M (2013): Factors Affecting Agricultural Productivity Among Arable Crop Farmers in Imo state, Nigeria. American Journal of Experimental Agriculture, Vol 3, Issue 2. PP32

Odoemenem I.U. and Obinne C.P.O. (2010). Assessing the Factors Influencing the Utilization of Improved Cereal Crop Production Technologies by Small Scale Farmers in Nigeria. Http://Www.Indjst.Org/Archive/Vol.3.Issue.2/Innocent-17

Onyeabor, E.N. and Ashiegbu, G.N. (2017). Analysis of Rural Livelihood Systems in Ebonyi State, Nigeria. Journal of Agriculture, Socioeconomics and Sustainable Environment, Vol. 5, No. 1

Septien S (2015): How Do We Solve Africa's Sanitation Problems? World Economic Forum, www.weforum.org

Simonart T, Roussel S, Gireaudot-Liepman M F (2013): Desk study on European standard for the enumeration of viable helminth ova in sludge, Soil and solid waste, Horizontal WP3-5Draft Report on Helminth ova. Techniques, Water Science and Technology 31:443-446.

UNICEF/WHO (2012). Building a future for and Children. UNICEF, Geneva. www.unicef.org $>$ count Down to 2015 UNICEF (2015). The State of World's Children. UNICEF, Geneva UNICEF (2015). Levels and $\bar{T}$ rends in Child Mortality Report 2015 Child Mortality Estimates. UNICEF, G e n e v a . www.childmortality.org

UNICEF/WHO (2010): Progress on toilet and drinking-water-2010 update. World Health Organization, Geneva

UNICEF/WHO (2015). Progress on Sanitation and Drinking Water - 2015 Update and MDG Assessment. UNICEFand World Health Organization, Geneva, Switzerland. https://sanitationupdates.wordpress.com

UNICEF (2008). Water, Sanitation and Hygiene Annual $\mathrm{R} e \mathrm{p}$ o $\mathrm{r}$ t . U N I C E F , Geneva.www.unicef.org > wash $>$ files. UNICEF

world Bank (2015): World Development Report: Mind Society and Behaviour, World Bank, Washington D.C.

WHO, (2004): Hutton G, Haller L Evaluation of the Costs and Benefits of Water and toilet improvement at the global level. Geneva: World Health Organization; 2004

WHO (2007) A Guide to the Development of on-Site T o i l e t, a c c e s s e d at http://www.who.int/water t o i 1 e t health/hygiene/envsan/onsitesan/en/on 14 June2007. 